\title{
EFFECT OF PRECISION LAND LEVELING ON RICE RESPONSE TO BIOFERTILIZATION IN SANDY SOILS
}

\author{
Bahnas, O. T. *
}

\begin{abstract}
This study was carried out at Kalabsho Region, El-Dakhlia Governorate, during 2006 summer season to find out the effect of precision land leveling on rice response to biofertilization in the sandy soils. The experiment was designed statistically as a split plots with three replicates. The main plots were located for the laser land leveling treatment levels of 0.00, 0.01, 0.02 and 0.03\% slope, comparing with the traditional leveling and the sub plots were devoted for the biofertilization treatment levels of Blue green Algae, organic activator (ascorbic acid + sitric acid, 38\%) and Blue green Algae + organic activator, comparing with the bereaved of biofertilization. The obtained results could be summarized as follows:

1. the precision land leveling under the biofertilization conditions achieve lower soil bulk density than the traditional leveling by about $7 \%$.

2. the precision land leveling under the biofertilization conditions achieved higher concentration of the available soil $N, P$ and $K$ than the traditional leveling by about 5, 21 and 9\%, respectively.

3. the precision land leveling under the biofertilization conditions enhanced to uptake more soil $N, P$ and $K$ by rice plants than the traditional leveling by about 30, 23 and $24 \%$, respectively.

4. The precision land leveling of $0.02 \%$ slope under the biofertilizer Blue green Algae + the organic activator achieved the higher rice grain yield of 4.15 ton/fed.
\end{abstract}

Finally, it is recommended to apply the precision land leveling, which increases the rice plants response to the biofertilization to achieve higher rice grain yield.

\section{INTRODUCTION}

gypt has adopted a strategy for rationalization of water use. This could be done through reducing the cultivated area with high irrigation demand crops such as rice which is the most important

\footnotetext{
* Senior Researcher at the Ag. Eng. Res. Inst. (AEnRI), Giza.
} 
staple food after wheat and a second major export agricultural commodity (Helmy et al., 2000). On the other hand, Egypt faces a growing imbalance between agriculture production and population increase. Both the vertical and the horizontal expansionism should be contributed to achieve a balance between the population food consumption and agricultural production. About 2.38 million feddans of sandy desert soil close to Nile Delta and Nile Valley could be added to the cultivated area. Improving fertility of the new reclaimed sandy soils may share in this respect (Khadr et al., 2004).

Rice unlike other cereals, especially the developed short duration cultivars, has a remarkable adaptation to a wide range of hydrological conditions. It is the most common crop in the newly reclaimed sols where the high salinity prevents the successful growth of many other crops (Mourad et al., 2003 and El-Refaee (2007).

The sandy reclaimed land of the coarsest structure has largest pore sizes, then, the particles do not compact. So, the sandy land has a higher aeration, a rapid drain and poor fertility (El-Banna; 1998 and El-Serafy and El-Ghamry; 2006). Hence, the modern techniques such as the precision land leveling and the biofertilizers must be applied to cause some useful changes in the sandy soil properties to become a good media for rice plants growth.

Land leveling is a common agricultural practice which is carried out to improve the irrigation water distribution and the soil conservation. Rice plants growth such as all crops depends to a great extent on the accuracy of the land leveling. However, the traditional land leveling method is labor-intensive, crude and do not achieve a high level of smoothness of land surface. On the other hand, the precision land leveling offers a great potential for water irrigation saving (El-Raie et al., 2003). The exact amount of the necessary water for plant growth which is accompanied with the uniformity distribution to all the field parts, leads to the Uniform germination and maturity, ultimately, increasing the crop yield (Gabber, 2001). Moreover, the land that has been contrived leveled has more desirable flooding, which increases the nutrients availability (Miller, 1990 and Miller et al. 1990). Also, the improved water coverage enhances the weed control (Singh and Dash, 1986). In addition, the laser 
land leveling makes it is possible to use of larger fields, increasing the farming area, leading to increase the machinery operational efficiency (El-Behery and El-Khatib, 2001 and El-Sahrigi et al., 2002).

With the steadily increasing the price of the chemical fertilizers and the pollution problems, the atmospheric dinitrogen-fixing systems are becoming more and more important. Fixation as an alternative or supplementary source of nutrients for rice has been the major approach in soil fertility management of nitrogen fertilizer for rice. A number of researchers such as Yanni, (1992) and Singh et al., (1992) found that the biofertilizers can help in increasing the yield without causing the disadvantages associated with chemical fertilizers. The biofertilizers are extremely beneficial in enriching the soil with those micro-organisms, which produce organic nutrients for the soil. El-Kalla et al., (1992); Hammad, (1994) and Sharif et al. (1998) applied the Blue green Algae in the clay soil. They found that the biofertilizer increased rice plant Nitrogen content at booting stage, plant height, effective tillers at maturity, panicle weight and grain yield.

The main objective of this study is identifying the effect of precision land leveling on rice response to biofertilizers in the sandy soils.

\section{MATERIAL AND METHODS}

\section{Experimental Procedure:}

\section{Experimental site and soil characteristics:}

During 2006 summer season, a field experiment of 1.50 fed. (100 x 60 m) was conducted at Kalabsho Region, El-Dakhlia Governorate. The soil was analyzed mechanically and chemically according to the standard procedures as described by El-Serafy and El-Ghamry (2006). The soil was sandy characterized by: sand, $80.50 \%$ (coarse, $77.28 \%$ and fine, $3.22 \%$ ); silt, $6.60 \%$; clay, $12.90 \%$; moisture content (w. b.), $16.38 \%$; bulk density, $1.64 \mathrm{~g} / \mathrm{m}^{3}$; pH (1: 2.5 Susp.), 7.33;Ece, 1.07 dSm${ }^{-1}$; O.M., 1.08\%; $\mathrm{CaCo}_{3}, 2.96 \%$; available $\mathrm{N}, 17.80 \mathrm{ppm}$; available $\mathrm{P}, 7.74 \mathrm{ppm}$ and available K, 280.00 ppm.

\section{Agricultural tractors:}

The following genral purpose agricultural tractors were used: 
1) Fiat $4 \mathrm{WD}(90 \mathrm{~kW}$ at $2500 \mathrm{rpm})$ tractor $110-90 / 110-90 \mathrm{dt}$ model was used as a mobile power for the laser control leveling equipment.

2) Ford $2 \mathrm{WD}(60 \mathrm{~kW}$ at $1000 \mathrm{rpm})$ tractor 7610 model was used as a mobile power for the chisel plough, the tandem disc harrow, the hydraulic scraper and the seed drill.

\section{Agricultural practices:}

() Tillage:

The seed bed was prepared using a mounted chisel plough in two perpendicular directions at $0.20 \mathrm{~m}$ depth. Then, the secondary tillage was conducted using a trailed tandem disc harrow.

\section{2) Land leveling:}

The traditional leveling was performed using a mounted hydraulic land leveler of $1.26 \mathrm{~m}^{3}$ capacity $(0.60 \mathrm{~m}$ length, $3.00 \mathrm{~m}$ width and $070 \mathrm{~m}$ height). While, the precision land leveling was performed using the same hydraulic land leveler which was accompanied with a laser control equipment that consists of the following parts:

a. Transmitter: The transmitter Spectra-physics 1145 laserplane has the following specifications:

a) Out put: Infrared laser. The reference plane of laser light can be tilted from $0 \%$ to $9.99 \%$ grade in two axes that are perpendicular to each other. The beam of light rotates at $600 \mathrm{rpm}$.

b) Power requirement: Internal battery powered gallium arsenide diode.

b. Control box: The control box CB2MTD has the following specifications:

a) Size: $0.17 \times 0.24 \times 0.14 \mathrm{~m}$.

b) Mass: $1.50 \mathrm{~kg}$.

c) Elevation display graduation: $0.5 \mathrm{~cm}$.

d) Operating temperature: -28 to $+71{ }^{\circ} \mathrm{C}$.

e) Electrical input: 12 or $24 \mathrm{~V} \mathrm{DC}, 10 \mathrm{amp}$. Max.

f) Electrical output: 12 or24 V DC, $4.5 \mathrm{amp}$./valve output.

g) Electrical connector: Standard military type.

c. Receiver mast: The Receiver mast has the following specifications:

a) Retracted height: $1.58 \mathrm{~m}$.

b) Extended: $2.77 \mathrm{~m}$.

c) Mass: $19.00 \mathrm{~kg}$. 
d) Operating temperature (ambient): -28 to $+71{ }^{\circ} \mathrm{C}$.

d. Receiver unit: The receiver unit has the following specifications:

a) Beam acceptance angle: $360^{\circ}$.

b) Vertical sensing range: $18.59 \mathrm{~cm}$.

c) On-grade dead band: $\pm 0.45 \mathrm{~cm}$.

d) Mass: $1.30 \mathrm{~kg}$.

e) Size: $0.29 \times 0.11 \times 0.14 \mathrm{~m}$.

f) Electrical input: 12 or $24 \mathrm{~V}$ DC.

g) Electrical connector: Standard military type (mil spec C-5015).

h) Operating temperature: -28 to $+71{ }^{\circ} \mathrm{C}$.

e. Telescoping grade rod: The telescoping grade rod 1084 English has the following specifications:

a) Size: Extended $180 \mathrm{H}$ x $1.7 \mathrm{~W}$ x $4.2 \mathrm{D}$ inches.

b) Retracted $54 \mathrm{H}$ x $1.7 \mathrm{~W}$ x $4.2 \mathrm{D}$ inches.

c) Mass; $2.27 \mathrm{~kg}$.

\section{3) Sowing:}

The selected seeds of Giza 178 short duration rice variety (135 days), which were produced by Rice Dep., Field Crops Inst., Ag. Res. Center, were sown with a rate of $60 \mathrm{~kg} / \mathrm{fed}$. using a mounted Sulky seed drill of 21 rows with $0.15 \mathrm{~m}$ row spacing.

\section{4) Fertilization:}

a) The mineral $\mathrm{N}$ fertilizer in the form of Yuria $(46 \% \mathrm{~N})$ with a rate of $69 \mathrm{~kg} \mathrm{~N} / \mathrm{fed}$. was applied in four equal doses. The first was applied before sowing and the others were applied 20, 40 and 60 days after sowing.

b) The biofertilizer in the form of blue green Algae powder with the rate of $0.50 \mathrm{~kg} / \mathrm{fed}$ was applied, at the tenth day after sowing, it was mixed with a suitable quantity of softy soil, then, the mixture was broadcasted above the irrigation water surface.

c) The organic fertilizer in the form of the organic activator (organic material; $62 \%$ and ascorpic acid + citric acid; 38\%) was sprayed in two equal doses at 30 and 60 days after sowing. Each dose was applied with a rate of $0.20 \mathrm{~kg}$ organic activator, which was dissolved with 150 Lit water 
All other practices were done according to the recommendations of the Rice Res. Dep., Field Crops Inst., Ag. Res. Center, Ministry of Agriculture and Land Reclamation.

\section{Treatments:}

During the experiment, the following treatments were tested:

1. Precision land leveling: This treatment included the precision land leveling slope levels of $0.00,0.01,0.02$ and $0.03 \%$, comparing with the traditional land leveling.

2. Biofertilization: This treatment included the biofertlization levels of Blue green Algae, organic activator and Blue green Algae + organic activator, comparing with the bereaved of biofertilization (control).

\section{Statistical design:}

The experiment was conducted as a split plots statistical design with three replicates. The main plots involved the precision land leveling levels, the sub plots involved the biofertilization levels.

\section{Measurements:}

\section{Soil measurements:}

After harvest, across each experimental unit, three soil samples were extracted from 0-0.30 m layer using a core sampler. As sited by ElSerafy and El-Ghamry (2006), the mean values of soil bulk density and available soil macronutrients concentration were determined as follows:

a. soil bulk density $\left(\rho_{b}\right)$ :

$$
\rho_{b}=\frac{\text { soil dry mass }}{\text { core volume }} \mathrm{g} / \mathrm{cm}^{3}
$$

\section{b. Available soil macronutrients concentration:}

a) The available $\mathrm{N}$ was extracted by IMCKI solution.

b) The available $\mathrm{P}$ was extracted by Calcium chloride solution.

c) The available $\mathrm{K}$ was extracted by ammonium acetate $(\mathrm{Ph}=7.0)$ and determined by flame photometer.

\section{Crop measurements:}

\section{a. Nutrients uptake by rice plants:}

At harvest, across each plot, rice grain samples were collected from 12 plants. As sited by El-Serafy and El-Ghamry (2006), the samples were weighed and digested. The uptake $\mathrm{N}, \mathrm{P}$ and $\mathrm{K}$ by rice plants were determined as follows: 
a) The uptake $\mathrm{N}$ was determined using a micro-Kjeidahi procedure.

b) The uptake $\mathrm{P}$ was determined color metrically using the chirostammous molybophosphric blue color method.

c) The uptake $\mathrm{K}$ was determined using the flame photometer method.

\section{b. Rice grain yield:}

At harvest, for each experimental unit, an area of $1 \mathrm{~m}^{2}$ was taken randomly to determine the rice grain yield. This procedure was replicated three times, and the mean value was recorded. Then, it was calculated on basis of $14 \%$ moisture content (d.b.).

\section{Statistical Analysis:}

Microsoft Office Excel 2007 computer program was used to employ the the analysis of variance and the LSD tests for rice grain yield data.

\section{Regression and Correlation Analysis:}

Microsoft Graph 2007 computer program was used to carry out the simple regression and correlation analysis to represent the effect of the precision land leveling slope on the rice grain yield.

\section{RESULTS AND DISCUSSIONS}

\section{Effect Of Precision Land Leveling On Soil Bulk Density:}

Fig. (1) reveals the effect of the precision land leveling on the soil bulk density. Data show that the precision leveling achieved lower values of soil bulk density than that were obtained by the traditional land leveling by about $7 \%$. This finding may be explained that the traditional leveling accomplished the cohesive humid soil particles, which loses during the drying process. The irrigation water encloses the soil particles and separates them, one from another. During the soil drying, the particles gradually draw nearer one to another, leading to the soil lumps shrinkage, consequently, the soil bulk density increases.

As shown in the figure, as the leveling slope increased from $0.00 \%$ to $0.02 \%$, the soil bulk density decreased by about $8 \%$. It is attributed to the impact force between the scraper edge and the soil clods, which increases with the leveling slope, resulting in the smaller pore spaces between the soil clods, leading to lowering the soil mass per unit volume. While, as the leveling slope increased to be $0.03 \%$, the soil bulk density increased by about $4 \%$. It is attributed to the soil particles of the excessive smaller 
pore spaces, which draw one to another, creating a incorporated structure of higher resistance to moisture diffusion, consequently, the soil mass per unit volume increased, resulting in higher soil bulk density values.

data showed that the precision land leveling, which was accompanied with the Blue green Algae decreased the soil bulk density by about 9\%, comparing with the bereaved of biofertilization. It is due to the beneficial effect of the microorganisms, which are retained in the soil in voids between the particles, sticking one to another, increasing the free pore spaces per soil volume unit, consequently, the soil bulk density reduces.

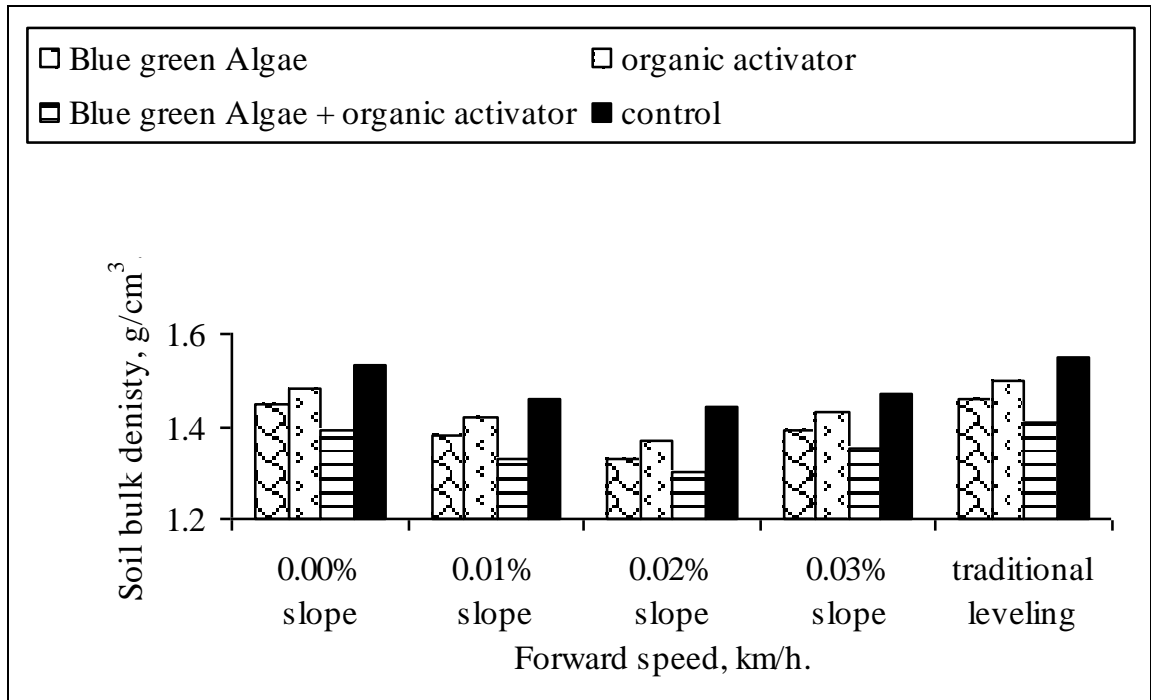

Fig. (1): Effect of laser land leveling slope on the soil bulk density.

\section{Effect Of Precision Land Leveling On Available Soil Macronutrients Concentration:}

As shown in Fig. (2), the precision land leveling achieved more amount of the available soil macronutrients concentration than the traditional leveling by about 5, 21 and 9\% for available N, P and K, respectively. It could be explained that the precision land leveling accomplished smaller soil particles, which having a negligible electromagnetic charge. So, the soil nutrients release increases. On the other hand, the traditional leveling achieved larger soil particles, which having higher surface tension that increases the soil bonding forces, leading to pore spaces increment, consequently, the the soil nutrients release diminishes. 
The Figure shows that the available soil macronutrients concentration increased with the leveling slope from 0.00 to $0.02 \%$ by about 19,17 and $4 \%$ for available $\mathrm{N}, \mathrm{P}$ and $\mathrm{K}$, respectively, then, it decreased at $0.03 \%$ leveling slope by about 16, 14 and 3\% for the previous macronutrients with the same respect. This trend could be illustrated that increasing the leveling slope from 0.00 to $0.02 \%$ achieves smaller soil particles of greater specific surface area, which allows to release more amounts of the available soil macronutrients, while, the minim soil particles that were occurred at $0.03 \%$ slope creat a compacted structure, which cumber releasing more amount of available soil macronutrients.

Blue green Algae Dorganic activator $\mathbf{Q B l u e}$ green Algae + organic activator $\square$ control

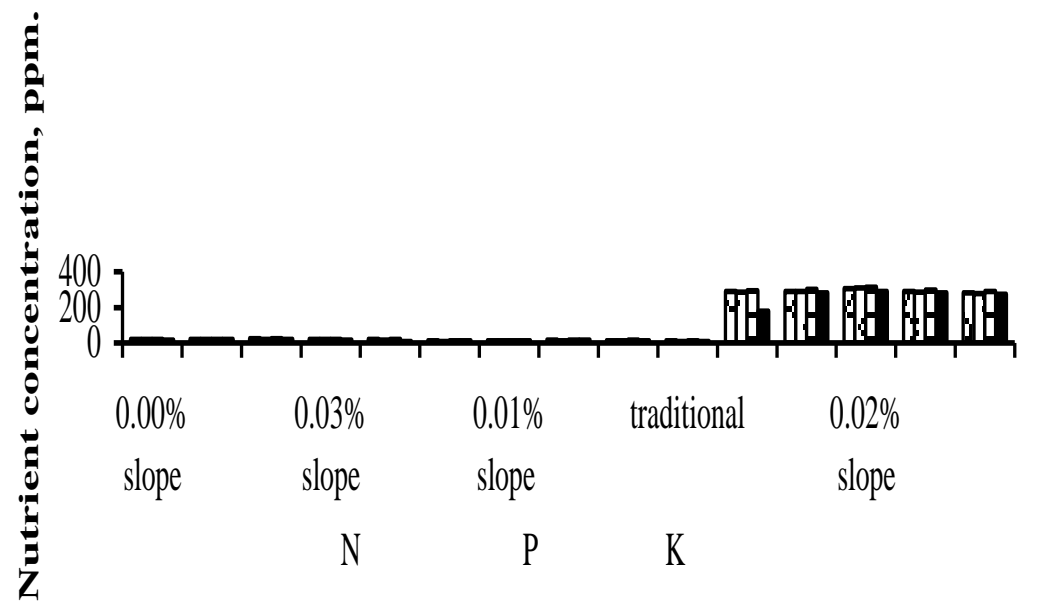

Fig. (2): Effect of laser land leveling slope on available soil macronutrients concentration. 
Data revealed that accompanying the precision land leveling with the Blue green Algae increased the concentration of the available N, P and K by about 16, 20 and $9 \%$, respectively more than the bereaved of biofertilization. This finding is explained that using Blue green Algae encouraged the biological fixation of the atmospheric Nitrogen that is related to the improved soil physical properties. Also, the increase in the available soil Phosphorus is due to the active Phosphate volatilizing by the soil microorganisms which is related to the desired soil structure. Furthermore, the increase in the available soil Potassium is due to the desired soil physical properties, which increased the release of the native Potassium source as well as the retention of Potassium b the organic soil clods against the soil leaching.

\section{Effect Of Precision Land Leveling On Soil Nutrients Uptake By Rice Plants:}

Fig. (3) indicates that The precision land leveling recorded higher values of the nutrients uptake by rice plants by about 30,24 and $23 \%$ for N, P and $\mathrm{K}$, respectively than the traditional leveling. It is attributed to the accurated leveled land which allowed to release more amount of the available soil nutrients, to be uptaken by rice plants.

Moreover, data revealed that using the biofertilizer Blue green Algae, especially, in case of the precision land leveling enhanced to uptake more nutrients by rice plants by about 8,13 and $18 \%$ for $\mathrm{N}, \mathrm{P}$ and $\mathrm{K}$ respectively. In addition, using the organic activator encouraged the fixation of the atmospheric Nitrogen, which increase the amount of $\mathrm{N}$ uptake. On the other hand, data exhibited that, there was non significant effect for the leveling slope on NPK uptake by rice plants.

\section{Effect Of Precision Land Leveling On Rice Grain Yield:}

Fig. (4) displays that the precision land leveling at $0.02 \%$ slope, which was accompanied with the biofertilizer blue green Algae + the organic activator achieved the higher rice grain yield of 4.15 ton/fed. This finding means that, the rice grain yield was affected significantly by the precision land leveling. It is due to the précised leveled land of the improved soil conditions, which enhanced the releasing the available soil nutrients, 
resulting in more NPK uptake by rice plants. In addition, the increased leveling slope from $0.00 \%$ to $0.02 \%$ increased slightly the rice grain yield,

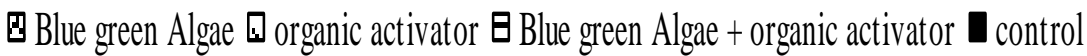

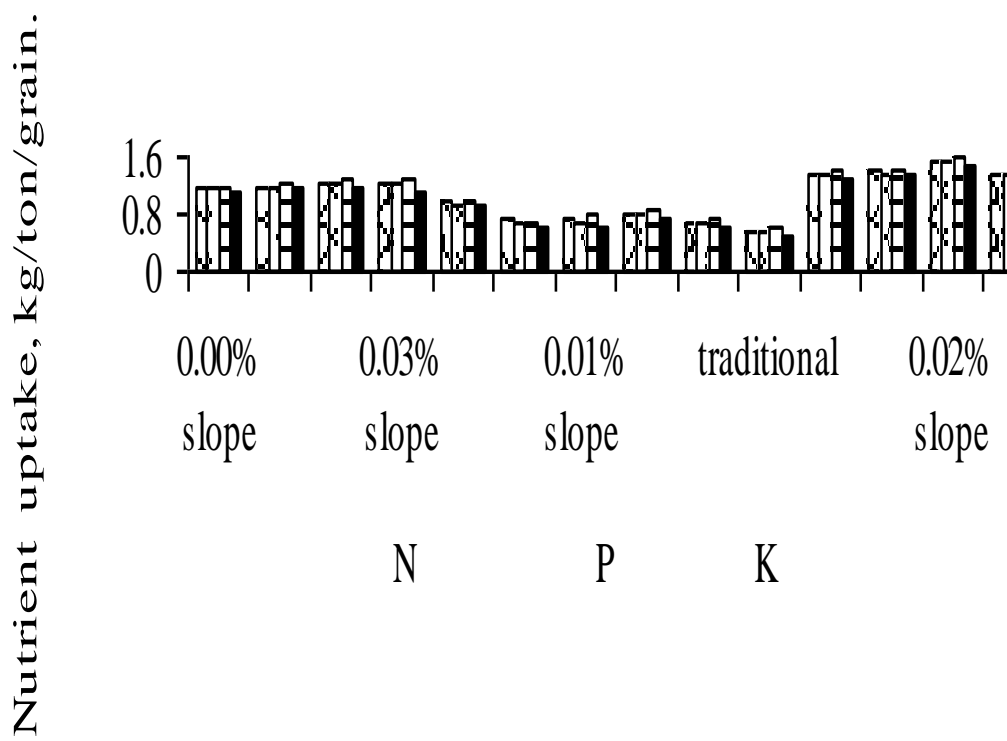

Fig. (3): Effect of laser land leveling slope on nutrients uptake by rice plants.

then, it diminished as the leveling slope increased to be $0.03 \%$. Moreover, the rice grain yield was affected significantly by the biofertilization, 
which improve the soil conditions. Furthermore, the use of the organic activator encouraged the biological fixation of the atmospheric Nitrogen. The analysis of variance test indicated that, there is a high significant difference in rice grain yield due to the leveling slope and the biofertilization. The L.S.D. test at 0.05 level showed that, the leveling slope of $0.02 \%$ which was accompanied with Blue green + Phosphoreen achieved the highest rice grain yield among the other treatments.

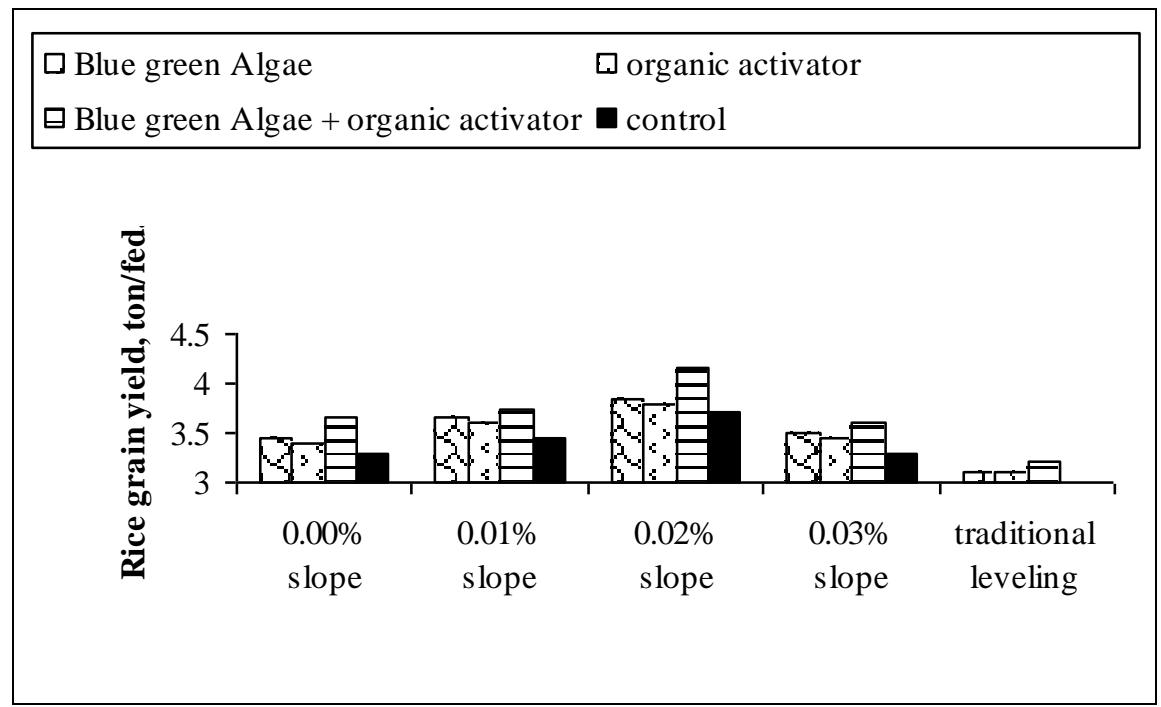

Fig. (4): Effect of laser land leveling slope on rice grain yield.

The regression and correlation analysis represented the relation between the leveling slope $(x)$ and the rice grain yield $(y)$ as follows:

Blue green Algae:

$y=-0.1250 x^{2}+0.665 x+2.890$

$\left(\mathrm{R}^{2}=0.9479\right)$

Organic activator:

$y=-0.1179 x^{2}+0.6321 x+2.870$

Blue green Algae + organic activator:

$y=-0.1390 x^{2}+0.7307 x+3.010$

Control:

$y=-0.1107 x^{2}+0.5893 x+2.800$

$\left(\mathrm{R}^{2}=0.8764\right)$

From the regression and correlation analysis, it can be noticed that, there is a positive correlation between the leveling slope and the rice grain yield. 


\section{CONCLUSION}

The obtained results of this study could be concluded as follows:

1. The precision land leveling achieve lower soil bulk density by about $7 \%$, increased the concentration of the available soil N, P and $\mathrm{K}$ by about 5, 21 and 9\%, respectively, enhanced to uptake more soil nutrients by rice plants by about 30,23 and $24 \%$ for N, P and K respectively and increased the rice grain yield by about $18 \%$, comparing with the traditional leveling.

2. The biofertilization achieve lower soil bulk density by about $9 \%$, increased the concentration of the available soil N, P and K by about 16,20 and $9 \%$, respectively, enhanced to uptake more soil nutrients by rice plants by about 8,13 and $18 \%$ for $\mathrm{N}, \mathrm{P}$ and $\mathrm{K}$ respectively and increased the rice grain yield by about $24 \%$, comparing with the bereaved of biofertilization.

It is recommended to use the laser leveling for rice production in sandy lands due to the higher field capacity and the higher rice grain yield, comparing with the traditional method.

\section{ACKNOWLEDGMENT}

The author wishes to express his sincere thanks and great appreciation to Eng. Mustafa Ahmed Gohar, Senior Ag. Specialist inEL-Dakhlia Ag. Experiments Direction, Ag. Res. C. and Eng. Mohamed Neiazy Abo-ElEz, Ag. Advisory and Adept in Ag. Experiments Direction, Ag. Res. C. for the veracious help during conducting this work in the field.

\section{REFERENCES}

El-Banna, E.B. (1998). Soil mechanics and water, $1^{\text {st }}$ Ed., El-Bardi Press, Mansoura, $444 \mathrm{p}$.

El-Behery, A.A. and S.E. El-Khatib (2001), The effect of precision land leveling on water use efficiency and performance for some farm machinery. J. Ag. Res. Review , 79 (4): 1513-1523, Ag. Res. Center.

El-Kalla, S.T.; A.A. Leilah and E.M. Said (1992), Effect of nitrogen fertilizer levels on the productivity of some rice cultivars. Priceeding $5^{\text {th }}$ conf. of Agronomy. Zagazig J. Ag. Res. (1): 133-140.

El-Raie, A.S.; A.M. El-Nozahy and R.K. Ibrahim (2003), Laser land leveling impact on water use efficiency, soil properties and machine performance under agricultural intensification conditions. Misr. J. Ag. En,. 20 (4): 757-775. 
El-Refaee, I.S. (2007), The interaction effect between water regimes and Potassium levels on growth, grain yield and water productivity in rice, J. Ag. Res., 85 (4): 1399-1421.

El-Sahrigi, A.F.; S.L. El-Khatib and A.A. El-Bahery (2002), Effect of farming operations on the duration of laser technology precision land leveling for successive seasons. J. Ag. Sci., Ain shams Univ., Cairo, 10 (1):59-71.

El-Serafy, Z.M. and A.M. El-Ghamry (2006), Methods of soil and water analysis (Practices), Soils Dep., Fac, Ag., Mansoura Univ., 253 p.

Gabber, K. A.E. (2001). Precision land leveling by using laser technology under the conditions of Fayoum Governorate, M. Sci. Thesis, Soils and water Dept. Fac. of Ag. at El-Fayoum Cairo Univ..

Hammad, S.A. (1994), Evaluation of Azolla and Ammonium Sulfate as asource of Nitrogen for rice production. J. Ag. Sci. Mansoura Univ. 19 (1): 375-385.

Helmy, M.A.; A.M. El-Serfy; S.Gomma; W.H. Abo El-Hassan; G. Fawzy and A. Nassar (2000), Effect of seed bed preparation and water management on yield and water requirement for rice. Misr J. Ag. Eng. 17 (4): 83-96.

Khadr, M.S.; R. Abou-El-Enein, A. Abd El-Shafy, F.A. Zahran and A.A. Zohry (2004), Sustainability of soil fertility status after 3-year crop rotation in sandy soils in Egypt. J.Ag. Res. 82 (2): 475-485.

Miller, D.M. (1990), Variability of soil chemical properties and rice growth following land leveling. Arkansas Farm Res. 39: 4.

Miller, D.M.; B.R. Wells; R.J. Norman and T. Alvisyahrin (1990), Fertilization of rice on leveled soils. p. 45-48. In W.E. Sabbe (ed.) Arkansas soil fertility studies 1989. Res. Ser. 398. Ark. Agric. Exp. Stn., Fayetteville, AR.

Mourad, S.A.; M.A. Ali; S.M. El-Awady and KH.A. Mowafy (2003), The roal of certain environmental factors on the population activity of rice leaf miner hydrellia prosternalis;deeming and leafhopper balclutha hortensis lindb, at the northern parts fo Delta. J. Ag. Res., 81 (4): 16191629.

Sharief, A.E.; M.H. El-Hinidi; A.T. El- Kassaby and F.I. Yossef (1998), Response of rice productivity to Biofertilization type and and nitrogen fertilizer level. J. Ag. Sci. Mansoura Unvi. 23 (12):5817-5825. 
Singh, B. and B. Dash (1986), Efficiency of different weed control methods in increasing grain yield of direct seeded unpaddled rice under irrigated conditions. Oryza, 23 (1): 50-52.

\section{Singh, A.L.; P.K. Singh; V.P. Pandey, A.K. Dubey and D.C. Veemd} (1992), Effect of blue-green Algae inoculation on yield of paddy in different districts of U. P. News. Agriculture. 3 (2): 189-192.

Yanni, Y.G. (1992), The effect of Cyanobacteria and Azolla on the performance of rice under different levels of fertilizer nitrogen. Biotechnology 8 (2): 132-136.

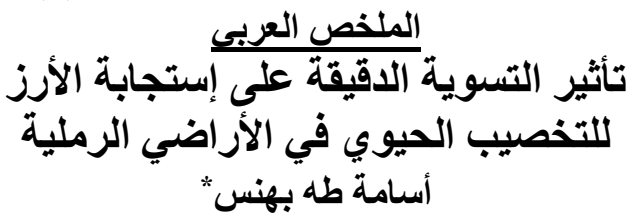

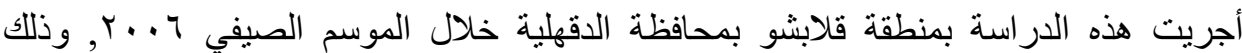
للوقوف على تأثير التسوية الدقيقة للتربة على إستجابة الأرز للمخصبات الحيوية في الأراضي

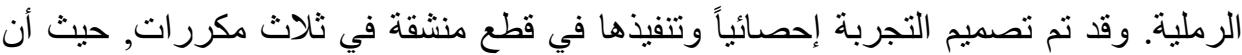

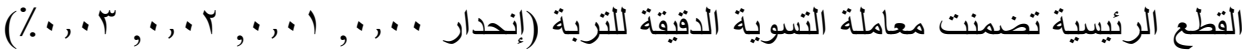

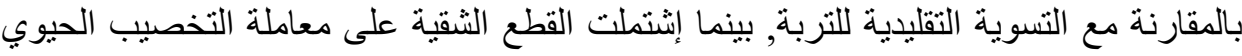

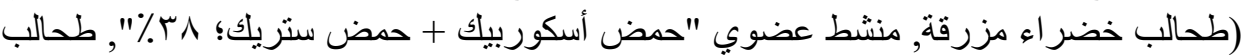

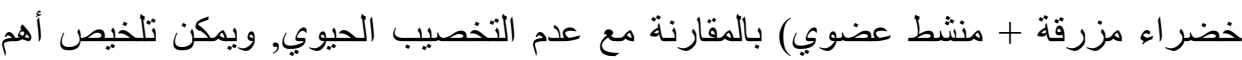

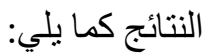
ا. . أدى إستخدام التسوية الدقيقة للتربة تحت ظروف التخصيب الحيوي إلى إنخفاض قيمة الكثافة الظاهرية للتربة بحو الي \٪ بالمقارنة مع التسوية التقليدية للتربة.

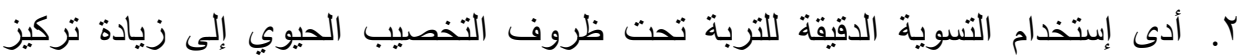

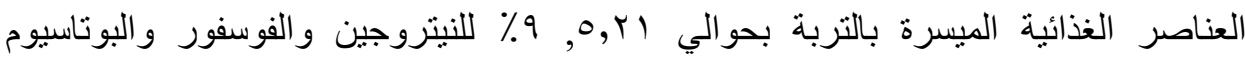
عالترتيب, بالمقارنة مع التسوية التقليدية للتربة. r. أدى إستخدام التسوية الدقيقة للتربة تحت ظروف التهابة التخصيب الحيوي إلى زيادة قدرة نباتات

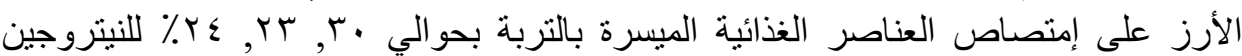
و الفوسفور و البوتاسيوم على الترتيب, بالمقارنة مع التسوية التقليدية للتربة.

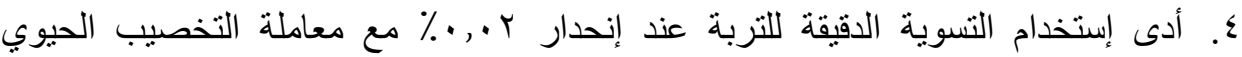

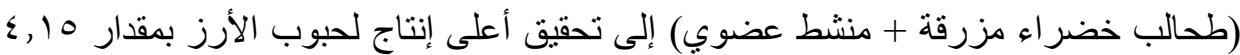

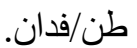
ولذا فإنه يوصى باستخدام التسوية الدقيقة للتربة التي تزيد من إسجابة نباتات الأرز للتخصيب

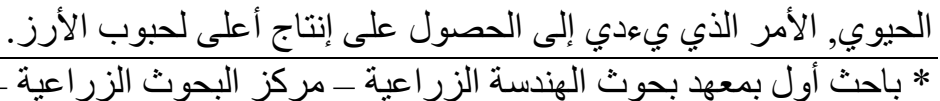

